\title{
AXEL HONNETH'S NORMATIVE PROPOSAL FOR THE RENEWAL OF HUMAN RIGHTS
}

\section{Paulo Vitorino Fontes}

pfontes@uevora.pt

Holder of a Ph.D. in Legal-Political Theory and International Relations and of Master and Bachelor Degrees in Sociology. He has participated in social intervention projects within the scope of European programmes. Author and participant in several projects, he has had coordination roles at Novo Dia - Association for Social Inclusion (IPSS). He was Regional Director of the Social Solidarity Section. He is a researcher at CICP - Centre for Research in Political Science at the University of Évora (Portugal). His main research interests are Political Science and Political Philosophy.

\section{Abstract}

This paper examines some aspects of Axel Honneth's normative theory, focusing on his theory of recognition, that can contribute to the renewal of human rights. To this end, it will start by making a few philosophical considerations about the justification and content of human rights, exploring the dialectic on the unity and diversity of human rights, in order to liaise the struggle for human rights and the struggle for recognition. It intends to move human rights away from the current inherent to Kantian philosophical thought, weakened by the decentralization of the European culture and conducted by 20th century postmodern reflections and by the critique of its categorical imperative as a pure duty of submission. It also examines the way to open space for a renewal of the discourse so as to enable it to confront delimited cultural and historical challenges. Other critical perspectives are included in this theoretical association, whether regarding the anti-utilitarian aspect, or the aspect of the gift paradigm, in order to contribute to the ethical renewal of human rights.

\section{Keywords}

Human Rights, Honneth, recognition, gift, ethics

\section{How to cite this article}

Fontes, Paulo Vitorino (2020). "Axel Honneth's normative proposal for the renewal of Human Rights". JANUS.NET e-journal of International Relations, Vol. 11, N.0 1, May-October 2020. Consulted [online] on the date of the last visit, https://doi.org/10.26619/1647-7251.11.1.1

Article received on July 14, 2019 and accepted for publication on March 30, 2020

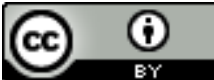




\section{AXEL HONNETH'S NORMATIVE PROPOSAL FOR THE RENEWAL OF HUMAN RIGHTS ${ }^{1}$}

\section{Paulo Vitorino Fontes}

\section{Introduction}

Human rights result from the process of the formation of the modern world. Their configuration is influenced by the general characteristics of the transition to modernity. As Gregorio Peces-Barba (1989: 268) underlines, human rights are not the abstract result of a rational reflection on the individual and his dignity, but a response to concrete problems in which they were undermined or diminished in the absolute State and in the context of the religious wars that took place in the 16th century.

The first individual, political and procedural rights that appear in history and which form the core of the declarations of the liberal revolution are not the result of a great rational reflection, but a response to a concrete situation existing in Europe and in the colonies of European countries in the $16^{\text {th }}$ and $17^{\text {th }}$ centuries. Although they were based on general ideas as they were being conceived, a consensus emerged on the initial catalogue of human rights. Thus, as Peces-Barba (1989: 269) points out, any attempt to justify or rationally renew human rights must take into account their historical starting point, which were dissent and struggle regarding the legal and political situation of the absolute State.

Over the years and struggles, the French Declaration of 1789 and the American Declarations of Rights provided the occasion for the historical emancipation of the individual from the social groups to which he had always been subjected: the family, the clan, the will and the religious orders. As Fábio Konder Comparato (2010: 68) stresses, it is important to mention that in this respect, the ground had been prepared over two centuries earlier. On the one hand, the Protestant reformation had decisively emphasized the importance of individual awareness regarding morals and religion. On the other hand, the culture of the exceptional personality, of the hero who forges his destiny and the destiny of his people, had been developed, especially in Italy during the Renaissance.

The evolution of human rights became much more substantive from 1945 onwards with the emergence of World War II, after massacres and atrocities of all kinds, which started with the strengthening of state totalitarianism in the 1930s,

humanity has understood, more than at any time in history, the supreme value of human dignity. Suffering as a matrix for understanding the world and men, according to the luminous lesson

1 This paper results from the last chapter, revised and updated, of the author's doctoral thesis (Fontes, 2016). 
of Greek wisdom, has deepened the historical affirmation of human

rights. (Comparato, 2010: 68-69)

The Universal Declaration approved by the United Nations General Assembly on 10 December 1948 and the International Convention on the Prevention and Punishment of the Crime of Genocide, approved a day earlier also within the framework of the United Nations, constitute the inaugural milestones of the new historical period, which is in full development.

We cannot, therefore, turn away from the challenge that Comparato poses us to find a foundation that goes beyond state organization in the practice of human rights. For Comparato (2010: 72), this foundation can only be the "collective ethical conscience, the conviction, long and widely established in the community, that the dignity of the human condition requires respect for certain goods or values in any circumstance, even if not recognized in the state order, or in international normative documents". This collective ethical awareness expands and deepens throughout history. "The demand for social conditions capable of enabling the realization of all human beings' capacities is thus intensified in time, and necessarily translates into the formulation of new human rights" (Comparato, 2010: 79).

Accordingly, this paper's challenge is to contribute to the expansion and ethical renewal of human rights, invoking some authentic assumptions from the political sphere, such as recognition and gift.

The justification of human rights poses additional difficulties to those who want to defend the ideals of this discourse. This justification is supported by a metaphysics of the nonobjectification of the human being, in the wake of the Kantian philosophical tradition, and, although defended by many authors, is weakened in contemporary thought. The use of Kant's transcendental categorical imperative constitutes the double problem of relying on a theistic view of the world to explain the existence of an absolute truth (Kelsen, [1960] 1998) - which may not find support in contemporary thought and, simultaneously, resulting in an empty norm, a clear-cut must be (Agamben, 2007: 5869).

In addition, the decentralization of knowledge conducted by history and culture shows, at all times, the partiality and contingency of metaphysical truths. As a consequence, oppositions to the human rights discourse are common due to its alleged ethnocentrism, denial of the subject's historicity and clear framing within an extensive history of Western interventionist political practices. In addition, the long and varied list of human rights finds wide support in the dignity of the human person, a legal principle whose intelligibility is conditioned by the realization of the rights it supports.

Nowadays, we face a rapid expansion of the Western way of life to all corners of the world. Often, under the veil of reason and image from the West, other cultures have been subjugated by an unequaled global capitalism whose consequences are, in an evident way, neither rational nor human.

In this context, Seyla Benhabib (2008: 179) stresses that "the legacy of Western rationalism has been used and abused in the service of institutions and practices that do not stand the scrutiny by the same reason which they claim to spread ". For the author, at the same time the planet becomes materially a single world, it is important to 
understand how the claims of universality can be reconciled with the diversity of life forms. This constitutes a relevant theme for International Relations, the complex dialectic of universalism and relativism or the unity and diversity of human rights, which will be examined next.

\section{On the unity and diversity of Human Rights}

The language of human rights has been the public vocabulary where the most pressing demands are made, as demonstrated by Michael Ignatieff (2003). The author draws on his vast experience analysing international affairs to offer us an intense narrative of the successes, failures and different perspectives of the human rights revolution. Since the United Nations adopted the Universal Declaration of Human Rights in 1948, this revolution has brought moral progress to the world through the continued expansion of rights, and has broken the supremacy of the Nation-State in the handling of international affairs. Ignatieff (2003) argues that human rights activists have drawn criticism from Asia, the Islamic world and the Western world for being overly ambitious and unwilling to accept limits. Therefore, the author argues, one of the main challenges is to reestablish a balance between the rights of states and those of citizens.

The expansion of human rights, as well as their defence and institutionalization, have become the indisputable language, although not the reality, of global politics. Benhabib (2008: 179), concerned with the question of the universality of human rights, defends the existence of a fundamental moral right inherent to all human beings, "the right to have rights" that Hannah Arendt ([1951] 1973 : 330) stated for the first time in her work Origins of Totalitarianism. In Benhabib's reinterpretation (2008: 179), "the right to have rights" is to be recognized by others and to recognize others as persons worthy of moral respect and legally guaranteed rights within a human community.

When disagreeing with the philosophical perspective that wants to reduce the content of human rights to a portion of what is internationally agreed, Benhabib (2008: 184) argues that it is necessary to develop the justification strategy and the content of human rights beyond the minimalist concerns, with a view to having a broader conception of human rights under the "right to have rights". The reconceptualization she proposes goes beyond Arendt's meaning, according to which the "right to have rights" was seen essentially as a political right, in the sense of the right to belong to a political community. Benhabib (2008: 184) proposes "a conception of the right to have rights, understood as the claim of each individual person to be recognized and to be protected as a legal personality by the world community". This broadening of the concept beyond the state sphere results from the gap Benhabib (2008: 184) detects in contemporary discourse on human rights, which fails to take into account the changes that have taken place with the shifting of legal norms from an international perspective to a cosmopolitan one.

Benhabib (2008: 184-187) analyses human rights from a discursive and theoretical perspective, in an attempt to understand the extent to which there are certain minimum assumptions about human nature and rationality that must underlie any normative formulation of human rights. For the author, universalism cannot be translated solely into a legal-political issue. Normative commitments are necessary so that justifying universalism is interwoven with moral universalism. 
For Benhabib, any political justification of human rights based on legal universalism must resort to justificatory universalism. Only by recognizing the communicative freedom of the other will the justification procedure be meaningful. However, there are different philosophical perspectives on the content of recognition. The distinctive feature of Benhabib's position (2008: 187) is "the interpretation of this communicative freedom in its relation to the right to have rights". The author departs from Kant's position and proposes a discursive-theoretical justification of the principle of law "instead of asking what each of us could will without self-contradicting to be an universal law, in discourse ethics we ask: "Which norms and normative institutional agreements could be considered valid by all those who would be affected by them if they were participants in special moral argumentations called discourse?" (Benhabib, 2008: 189).

The fundamental difference in the model proposed by Benhabib (2008) in relation to the various theories centred on the agent, is that it proceeds from "a view of the human agent as an individual embedded in contexts of communication as well as interaction. The capacity to formulate goals of action is not prior to the capacity to be able to justify such goals with reasons to others" (p. 189). Action and communication are inextricably linked. "I only know myself as an agent because I can anticipate being part of a social space in which others recognize me as the initiator of certain deeds and the speaker of certain words" (p. 190).

Here, even without mentioning it, Benhabib's discourse meets Axel Honneth's theory of recognition, as we will see later, since the conditions for intersubjective recognition will be able to guarantee the communicative freedom that Benhabib proposes.

For communicative freedom to be exercised, it will be necessary to respect each person's capacity for action and communication, to be recognized as a member of a human community in a social space of interaction. For Benhabib (2008: 190), having rights is

\begin{abstract}
a moral claim to be recognized by others as a rights-bearing person entitled to a legally instituted schedule rights. Others can only constrain your freedom as a moral being through reasons that satisfy the conditions of formality, generality, and reciprocity for all.
\end{abstract}

In addition, the right to have rights implies the acknowledgment of the other's identity, both "as a generalized as well as a concrete other". If we recognize the other only as a being who has the right to have rights just because he is like us, then we are denying his difference, his fundamental individuality. If we do not recognize the other as a being with the right to have rights due to his marked alterity in relation to us, then we are denying our common humanity.

For Benhabib (2008: 190-191), recognizing the generalized other requires considering others, each and every individual, as human beings who have the same rights and duties that we want to ascribe to ourselves. In this dimension, the individuality and the concrete identity of the other are abstracted and the moral dignity that we all have in common is emphasized. The type of relationship established is governed by the rules of formal equality and reciprocity. Each has the right to expect from others what we can expect from him. In treating the other according to these norms, I ratify the rights of humanity in the other and I legitimately hope that the other will do the same with regard to me. 
On the other hand, recognizing the concrete other requires regarding each and every one as human beings with an affective-emotional constitution, a concrete history and a unique identity. In this dimension, what we have in common is abstracted and we focus on individuality. The relationship is governed not only by equity and reciprocity, "but it anticipates experiences of altruism and solidarity" (Benhabib, 2008: 191).

Benhabib (2008) does not intend to describe human nature through the generalized and the concrete concepts. Above all, they are "phenomenological accounts of human experience" (p. 191), whose tensions the author does not analyse.

In relation to the generalized other, it assumes a universalist form based on the egalitarian experiences of modernity, albeit fragile and contestable, which may constitute practical possibilities that can be extended to all humanity.

Reciprocal recognition of each person as a being who has the right to have rights implies learning processes, political struggles and social movements. This is the authentic meaning of universalism for Benhabib (2008: 191):

Universalism does not consists in an essence or human nature which we are all said to have or to possess, but rather in experiences of establishing commonality across diversity, conflict, divide and struggle. Universalism is an aspiration, a moral goal to strive for; it is not a fact, a description of the way the world is.

Benhabib's justification of human rights (2008: 192) through a discourse-theoretic account of communicative freedom, which takes place in a dialogical practice, moves away from naturalistic perspectives and from possessive individualism. She understands the recognition of the other's right to have rights as an authentic precondition for the other to be able to contest or accept my first demand.

Her project called "interactive universalism", which is different from other contemporary positions, previously developed in her work Situating the Self (1992) and later expanded as "democratic interactions" in Another Cosmopolitanism. Sovereignty, Hospitality, and Democratic Iterations (2006), characterizes the interaction processes that occur between the democratic formation of will and opinion on the one hand, and constitutional principles and international law on the other. The concept aims to analyse the relationship between unity and the diversity of human rights, as well as the relationship between their moral nucleus and their legal form.

However, as Benhabib (2008: 196) admits, "the right to have rights seems quite abstract and formalistic". If human rights are principles that need to be contextualized and specified in legal norms, then how to formulate this legal content?

The answer given by Benhabib is "to proceed from the right to have rights (...) to the norms of equal respect and concern and to derive a concrete list of basic human rights in this fashion. Human rights would then find their place in moral philosophy" (p. 196).

But how can we account for the diversity of the world, its tremendous inequalities? How can an ethics of discourse that gives us only the minimum conditions for the dialogical procedure, which claim to be sufficiently tenuous so that they cannot be identified with any particular view of the world and, on the other hand, sufficiently consistent to guide 
the dialogue with a view to a rational consensus, contribute to the renewal of human rights?

This Habermas based view needs, in our opinion, the complementarity of Axel Honneth's theory of recognition, since the right to have rights implies a struggle for recognition, in which the acquisition of social recognition is the normative condition of all communicative action.

In view of these difficulties, by proposing to found a social theory with normative content in post-metaphysical contemporaneity, especially in the work entitled The struggle for recognition, Honneth's research gives us the appropriate tools for understanding and renewing the struggle for human rights.

The next objective is, in a first phase, to use Honneth's theory of the struggle for recognition, include the most recent update of Hegel's Law and explore his normative proposal regarding the conditions of an ethical life. Other critical perspectives will be included in this reflection, whether regarding the anti-utilitarian aspect or the aspect of the gift paradigm, in order to contribute to the ethical renewal of human rights.

\section{The theory of recognition in the renewal of human rights}

The idea of a struggle for recognition as a methodological key for understanding social conflicts was initially advanced by Hegel during the period called "Jena", as a reference to his stay in this city and to the theoretical instrument he developed, as a young teacher of Philosophy, whose internal foundation goes beyond the institutional horizon of his time (Honneth [1992] 2011: 13). It is from here that Honneth seeks the possibility of founding a new social theory with normative content, following the line of Horkheimer's previous contribution to critical theory. In this sense, Honneth ([2000] 2007: 66) intends to associate his project with the philosophical tradition of "left Hegelianism", which includes numerous authors and thinkers like Marx, Adorno and Habermas.

From the reinterpretation of Frankfurt theorists, Honneth proposes the existence of three assumptions that cross his analysis: (1) the declaration of a universal reason capable of making social movements intelligible; (2) the discordant performance of this reason as the cause of a pathology; and (3) an emancipatory goal identified from suffering (Honneth, 2009: 42).

The first two assumptions are open and, thus, it is not possible to check their empirical evidence. It is only from the last theoretical assumption that one can offer the theory a positive content that can be object of experimentation. Accordingly, Honneth proposes the construction of a social theory with normative content, dependent on the capacity for pre-theoretical verification of social suffering, capable of informing theoretical thinking of the relevance of an emancipatory will in society.

However, according to Honneth ([2000] 2007: 65), the Frankfurt School had remained tied to historical Marxist materialism, associating social suffering with the particular issues of a class, the proletariat, which was responsible for transforming its suffering into an emancipatory engine. But when history showed that the proletariat had transformed its suffering in support of the rise of fascism, the positive tone initially adopted by critical theory became out of step with society's understanding and transformation. 
However, for Honneth, what history shows as inadequate is only the specific positive content adopted by the theory, which was linked to the exploitation of work and not to its theoretical foundation, and the possibility of developing a social theory of normative content remains open, as long as we depart from suffering as revealing an emancipatory will in society. For this thinker, without any kind of proof that the critical perspective of the theory is reinforced by a movement in social reality, critical theory can no longer be followed in contemporary times, since it would not be possible to distinguish it from other models of social criticism, due to its claim of a superior sociological method or due to its philosophical justification procedures. For Honneth ([2000] 2007: 66), it is only through its attempt, which has not yet been forsaken, to provide criticism with an objective foundation in pre-theoretical praxis that it can be said that critical theory is unique and alive.

From this exercise, Honneth criticises Habermas' theory of communicative action, precisely because he does not find support in the clear diagnosis of social suffering. He argues that if communication is removed from the theory of language and understood as an intersubjective process, through which human identity develops, this suffering can be perceived in the deficient recognition of some identities and, thus, the criticism would find in this recognition its lost normative support (Honneth, [2000] 2007: 75). It then appears that the Hegelian philosophical project is rescued from a struggle for recognition.

In Honneth's theory ([1992] 2011), we notice an effort to conceptualize the three spheres of recognition: Love, Law and Social Esteem, initially identified by Hegel. These spheres of interaction, through the cumulative acquisition of self-confidence, self-respect and self-esteem, create not only the social conditions for individuals to reach a positive attitude towards themselves, but also originate the autonomous individual.

The sphere of love constitutes the primary affective relationship of mutual recognition that structures the individual since birth, and which is dependent on a fragile balance between autonomy and attachment. According to Honneth ([1992] 2011: 159-179), the symbiotically nurtured bond, which is formed by an initially mutually desired delimitation between the mother and child, creates individual self-confidence, which will be the fundamental basis for autonomous participation in public life. From the normative perspective of the generalized other that teaches us to recognize others as holders of rights, we are allowed to understand ourselves as legal entities. The sphere of law develops in a historical process, its development potential is verified in the generalization and materialization of the legal recognition relationships. In order to achieve an uninterrupted self-relationship, human subjects also always need, in addition to the experience of affective dedication and legal recognition, a social appreciation that allows them to relate positively to their concrete properties and capabilities. This is within the sphere of social esteem, a third relationship of reciprocal recognition based on the assumption of symmetrical valuing, according to which individuals consider each other in the light of values that make the other's capabilities and properties important for common experience. The symmetrical relationship does not mean a reciprocal appreciation in equal measure, but the challenge that any subject has the opportunity to experience himself as being valuable to society through his capacities and properties. Only in this way, according to Honneth's reasoning, under the notion of solidarity, will social relations be able to access a horizon where individual competition for social valuing may be free from experiences of disrespect. 
In the succession of the three forms of recognition, the degree of a person's positive relationship with himself progressively increases. With each level of mutual consideration, the individual's subjective autonomy also grows. Likewise, parallel experiences of social disrespect can be attributed to the corresponding forms of mutual recognition.

For Honneth, the practice of deviant behaviours would not only result in social disapproval, but in preventing the individual from having a positive recognition of himself in his action. This opens the possibility of transforming the collective ethics that allow the realization of the Self. In this sense, the struggle for social recognition of the subject's particularities would be the constant transformation engine of the ethical framework of a society, in order to include forms of individuality that in a given circumstance are subject to precarious recognition.

In order to rebuild the foundation of a social theory with normative content, along the lines of the project previously conducted by Horkheimer for critical theory, Honneth recovered the Hegelian philosophical project of the struggle for recognition. Although at first he was limited to looking for his bases in the thinking of the young Hegel, in more recent works (Honneth, 1999, [2001] 2010 and 2014), the author tried to link that intersubjective struggle to the notion of freedom formulated by the older Hegel, as opposed to the atomistic views of Kant and Fichte.

Honneth states that Hegel's theory of justice shares with these authors the centrality of the idea of equal individual freedom for all. However, his theory differs from the others in conceiving freedom as something that goes beyond a simple subjective right or a simple moral autonomy. For Hegel, adopting any of these views of the concept of freedom, in an isolated way, would lead to social pathologies resulting from the violation of the "absolute spirit" (Honneth, [2001] 2010: 25). In this Hegelian thesis, although of a metaphysical and historically situated nature, Honneth considers that there is a critical nucleus that must be transported to our days.

Honneth's (1999) proposal to update Hegel's Philosophy of Law does not intend to rehabilitate neither the methodical conditions of Logic, nor Hegel's basic conception of the State. But stripped of these elements, Hegel's Philosophy of Law can be conceived as "a project of a normative theory of those spheres of reciprocal recognition whose maintenance is constitutive of modern societies" (Honneth, 1999: 19). To address such a challenge, Honneth presents the remaining elements that allow this updating: the concept of "objective spirit" and the notion of "ethics".

\footnotetext{
The first concept (objective spirit) seems to me to include the thesis that all social reality has a rational structure, whose rejection through false or insufficient conceptions must lead, even where they are applied in a practical way, to negative consequences in social life. (Honneth, 1999, p. 19)
}

With regard to the concept of ethics, Honneth considers that it contains the thesis that in social reality "spheres of action can be found in which the inclinations and moral norms, interests and values are fused in the form of institutionalized interactions" (Honneth , 
1999: 19). Therefore, these spheres, and not the State, would deserve a normative characterization through the concept of ethics.

Based on these principles, Honneth (1999: 26) updates Hegel's theory of law in three stages. In the first, he presents a theory of justice based on the Hegelian concept of "free will" which, having been conceptualized in opposition to atomist perspectives, determines the full scope of what we must call "right". The difficulty of this fundamental intuition is related to Hegel's thesis that "the will has itself as an object". Honneth interprets this idea based on Hegel's definition of love: "Being yourself in the other". With this interpretation, the focus shifts to the existence of social and institutional conditions, seen as fundamental, as they should allow the subjects' communicative relationships. For Honneth, those spheres, expressed in institutions and systems of practices that are irreplaceable to enable self-determination socially, are the authentic bearers of rights. Thus, Philosophy of Law is understood as the theory of the social conditions that enable the realization of "free will", which goes towards a normative theory of social justice.

From this perspective, Hegel's theory of law is divided into three divisions. The first two are "Abstract law" and "Morality", where Hegel addresses the incomplete conditions for the achievement of free will, in the form it takes, respectively, modern rights or capacity for moral self-determination. The third part, "Ethics", deals with complete conditions, distinguishing three spheres of communicative action: the family, civil society and the State. From then on, the theory of justice is articulated with the diagnosis of the time, constituting the second stage of Honneth's updating proposal.

Honneth (1999) compares Hegel's claim with Habermas's argument in Facticity and Validity. For Habermas, "the legitimacy of the legal-state order comes from the guarantee of the conditions of democratic formation of the will", while in Hegel "it goes back to individual self-realization to have from its conditions the task of a modern legal order" (Honneth, 1999: 43).

Hegel gives a vast description of the concepts contrary to freedom, as a trend of the time. What hinders his task is: "To highlight, in the development of his theory of justice, the necessary function that legal freedom and moral freedom assume in relation to the conditions of communicative freedom, which are evident in the ethics concept" (Honneth, 1999: 45).

In the first part of Hegel's work on abstract law, he argues that calling for it is only a possibility, something about the whole set of circumstances. Using this faculty would depend on quasi-characterological factors and result in suffering: "The person who articulates all his needs and purposes in the categories of formal law is unable to participate in social life and, therefore, will suffer in indeterminacy" (Honneth, 1999: 50). But, on the other hand, one can recognize the value of the formal right in relation to individual self-realization, since the subject, seeing himself as a holder of rights and by showing the limits imposed by social relationships, has the opportunity to withdraw behind ethics.

In the second part of the book, which corresponds to morality, Honneth reconstructs Hegel's argument to show the relationship between the limits the subject stumbles over when conceiving unilaterally, in a moral way, the realization of his freedom and the reasons that foster the passage to the sphere of ethics. Hegel's criticism is directed against Kant's categorical imperative, as its application results in disorientation and a feeling of emptiness. Kant believed that his categorical imperative would apply wherever 
there was a moral conflict. However, according to Hegel, the formality of the imperative led to the abstraction of the social environment, where concepts and moral points of view are already institutionalized, and so, the imperative loses its founding function.

So that Hegel's argument is not understood as moral relativism, Honneth (1999: 53) argues that "the concept of ethics is a theoretical-moral argument in a narrow sense" and that the proposal to understand social reality as an incarnation of free will represents an epistemological and social ontology argument. When we do not consider the ethics or the sufficient rationality of social institutions, which become second nature, the subject is abandoned to interior emptiness and poverty of action. Therefore, the path to ethics must be experienced as a liberation, not only for abandoning incomplete conceptions, but also for its therapeutic effect on a pathology in the world of life that causes suffering. Thus, it should be understood as an "achievement of affirmative freedom" (p. 53). This way, Hegel's Philosophy of Law presents a phenomenology of the configurations of freedom, with an equivalent theory of justice, where free conscience is linked to the diagnosis of the time, and these elements converge in the ethics doctrine.

Honneth's final action is to update the ethics doctrine in a normative theory of modernity. To this end, he established self-realization and recognition as fundamental conditions. "Only in an action whose execution is characterized by the fulfilment of certain moral norms can a subject guarantee to be recognized by others, because this recognition is determined precisely by the moral competences, which are established through the corresponding action norms" (Honneth, 1999: 53).

Thus, the normative content of ethics is an articulation of the forms of intersubjective action that can guarantee recognition due to their moral quality. In this sense, the family, civil society and the State are constituted as social spheres with fields of practice, which can guarantee individual freedom in its modern configurations that combine recognition, creation and self-realization.

The renewed theory of the struggle for recognition appears as a model to understand social conflicts as ethical claims that contribute to the expansion of the subjectivation possibilities and alter the ethical framework of the whole. Thus, the transgression points to the ethical insufficiency of the collective, not of the transgressing individual. The focus of law intervention is inverted, ceasing to be centred on the individual, on the need to adapt him to social conventions, to focus on society and on its need to recognize and include the most diverse modes of existence, guaranteeing their physical survival and valuing their uniqueness.

After presenting the struggle for recognition, which, in order not to fail, needs ethics with normative content, this article examines other critical contributions and completes the moment of struggle with that of gift, as both are poles of a recognition relationship. Only in this way the conditions for a renewal of human rights are met, both at collective and individual levels, since human rights are, at the same time, the legitimizing basis of law and the moral foundation that inspires our lives.

According to Flávia Piovesan (2010), the complementarity between the different dimensions of human rights already has doctrinal and legal recognition. However, it is not clear to what extent they are based on the Kantian or to the natural law philosophical theoretical framework to which human rights usually refer. The ideal of not objectifying human beings seems to support the dimension of civil liberties and social rights. Since the human being should not be treated as an object by his fellow men, then his body 
must enjoy immunity. This includes renouncing direct action on him and guaranteeing all his needs, to avoid that, abandoned, he is forced to surrender to the will of the other. However, with regard to political rights and the right to difference, the Kantian ideal does not seem to provide an adequate basis, since it does not seem possible to base political participation and the recognition of the right to difference on the non-objectification of human beings.

In the same way that the categorical imperative of acting so that his behaviour can, out of his own will, become universal law. In addition to not providing material consistence and admitting any behaviours and imposing a duty void of meaning, it seems to be, ultimately, opposite to the recognition of diversity. From it, it is not possible to derive a need for recognition of the difference of the other, but on the other hand, it can be demanded that the other resembles, in his behaviour, the Self.

Accordingly, the Kantian abstract formalism proves to be insufficient to support the theme of human rights and does not seem to be able to substantiate the new themes that have been incorporated in the struggle for human rights, which Western rationality was unable to include in its historical development.

Whereas Western modernity offers us essential values, such as freedom and authenticity, according to Charles Taylor ([1992] 2009) it also brought us profound problems: egocentric individualism, the primacy of instrumental reason and the loss of freedom. Since individualism is shaped by the ideal of authenticity, Taylor seeks the deeper meaning of this ideal, with the aim of reinvigorating the ethics of authenticity. What is new and important in Taylor's thinking ([1992] 2009) is the idea of a more complete and original individuation that has always been part of a community of meaning. Each individual is unique and must live according to his uniqueness and originality. More than observing the differences between individuals, it is important to realize that these differences imply the duty to live according to this originality. Thus, in contrast to the standardization and generalization of an instrumental perspective in relation to self and others, it is the articulation of my originality with others that defines us as people. Thus, authenticity, as a moral ideal, is essentially dialogical and intersubjective, since authenticity is the unique expression of the self, more in the form than in content, built on inner, intrapsychic dialogue with others who are significant to us. From here, we build and reconstruct our identity in a continuous recognition relationship. Authenticity is only achieved through intersubjective recognition. Duly articulated and recognized authenticity enables the most complete form of human fulfilment.

Thus, the recognition theory as an alternative paradigm seems appropriate. Recognition is a multidimensional phenomenon - intersubjective, social and political - in which one cannot speak of full recognition until the conditions for the full fulfilment of individuality are guaranteed, until the subject's autonomy in his historical singularity is ensured, and the freedom of the body, moral autonomy and the dignity of his individuality are safeguarded.

Rather than imposing the particular subjectivity patterns of globally dominant cultures, human rights become a means of defending the forms of subjectivation that are present within local cultures, but which are poorly recognised. Thus, instead of enclosing the content of human rights in foreign standards and pretensions, their borders are opened to different historical and cultural situations. 
One of Silvério da Rocha-Cunha's (2015: 169) central ideas is "the need for a New World Culture, where everyone gives and receives without fear, especially without that border fear that delimits territories and legitimizes the split between friend and enemy". A cultural liberation that implies, according to the author, a previous political-cultural liberation. Only through the creation of conditions that allow dialogue can the major socio-economic and ecological problems of our era be solved.

"These problems have reached a dimension that risks reaching a point of no return" (Rocha-Cunha, 2015: 176). The relentless logic of economic growth, which exploits the other, degrades social ties, continues to grow at the expense of sustaining the planet and future generations. For him, the economic issue needs questions of an ethical nature, in order to establish a global economic theory based on justice with the peoples of the Earth and with future generations.

In this sense, Juan Ramón Capella (2005 and 2007), starting from a philosophicalpolitical reflection around the central problem of the contemporary world: its ecological and social crisis in the midst of a technological revolution, the real universalization of economic relations, the new supra-state sovereign powers, the crisis of citizenship and the assumptions of political intervention; proposes, in the face of a world that abandoned the "good life" - the object of ethics - the reconstruction of social bonds: the search for new bonds between people, free bonds, not mediated by the State. To this end, it will be necessary to relearn solidarity, help and understanding among people and appreciating their diversity. The objective is to reconstruct the bonds, similar to those that in the past linked people, stripped of the "metaphysical" character, involuntary and unconscious, but that allow the common learning of new forms of life and civilization.

Thus, as Rocha-Cunha (2015: 177) stated, "an attitude of positive expectation regarding the fruitful contributions of other cultures is required. It will then be possible to have a kind of intercultural reconciliation that will know how to resolve the systemic crises that overwhelm our planet".

Due to the imposition of Western standards, colonialism that did not cease to exist within societies and, to a large extent, in relations between the North and the South, so, enormous obstacles and difficulties arise in the construction of a dialogue between cultures. As Rocha-Cunha (2015: 178) refers, these are problems that are linked to the logic of social systems themselves, as these tend towards progressive simplification and continuous internal adjustment with a view to their maintenance. So they look for simple certainties, instead of looking for the other, the different, pluralism and human complexity. On the other hand, the supposed universalism of the West and its lack of respect for other cultures, mainly from the African and South American continents, has turned vast dialogues into an empty list of commitments.

Boaventura de Sousa Santos (2003), concerned with establishing fruitful intercultural dialogues, considers that all cultures are incomplete and problematic in their conception of human dignity. Incompleteness stems from the existence of a plurality of cultures and this is understood better from the outside, from the perspective of another culture. If each culture were as complete as it intends, there would be only one culture. Thus, raising the awareness of cultural incompleteness to the maximum proves to be one of the most important tasks for the construction of a multicultural conception of human rights. 
According to Francesco Fistetti (2007: 297), the pursuit of purely utilitarian interests or power on the part of dominant countries has fuelled the negative aspects of globalization, to the extent that these effects backfired against the same countries. The logic of the market without rules ends up leading, sooner or later, to violence, war and barbarism. The lesson that Marcel Mauss ([1924] 1988) proposes is to temper private interest with general interest: securing peace above the idea of a common wealth and the idea of a common world. We could thus say that any people, any culture or nation intends to give something specifically its own to the large family of peoples, nations and cultures, and wishes to be recognized and rewarded for that contribution: it intends to be part of the giving-receiving-giving back cycle, but in a broader sense, not only in economic terms but also symbolic and cultural. Like the producer who has the feeling of giving something that is not reducible to his working time, but which is related to the gift of self and his existence, also the poorest and most excluded peoples and nations should not be considered mere operators of a supposedly equal exchange, dependent on the "Homo ecunomicus" model, since the exchange is unequal from the beginning, since the material inequality of the subjects (Fistetti, 2007: 298).

We must understand others and otherness as worthy of respect, accept difference as difference and not as indifferent, capable of enriching our humanity and our view of the world, recognizing them as capable of giving something that we do not have. As Julien Rémy \& Alain Caillé (2007) point out, peoples who give confiscate the moment of donation, becoming those who give, that is, those who always give whout receiving anything in return, not expecting more recognition from those who receive it. Here, the domination relationship lies in the fundamentalism of a cultural conception based on selfcentred Western rationality which sees the other as a simple reflection of himself.

For Alain Caillé (2010), the theories of justice, in the line of John Rawls, present the problem of not breaking off with a utilitarian conception of the human subject. As Amartya Sen shows, they aim at an unattainable ideal and have nothing to say in specific cases.

On the other hand, Caille underlines that there is another major theoretical and political debate in the world that takes place around recognition theories. All subordinate, postcolonial, cultural, and feminist studies, among others, address the issue of recognition, albeit from different perspectives. For them, a good society would be one where no one would remain invisible, unknown or poorly recognized. The problem with these approaches, in turn, is that they feed on the competition of the victims. They do not answer the question of who should give recognition to whom; a recognition that cannot be distributed in the same way as monetary income. And, finally, they leave the question of the amount to be granted to those seeking recognition undetermined, such as the ultimate values in the name of which recognition can be granted.

Recognizing a culture means giving it a unique and irreplaceable value within cultures and civilizations. From this perspective, we can understand Caillé's views about the social value of people and affirm that the value of a culture can be measured by its ability to give, both in the gifts actually made and in its potentialities for giving, or ability to give. And going back to Caillé's question: what will be the evaluation criteria, the potency or the act of giving? It becomes evident, just as among people with regard to cultures, that it is not a matter of establishing an axiological hierarchy between higher and lower cultures, but it is about the phenomenological sense of the gift (das Ergebnis), as highlighted by Hannah Arendt ([1958] 2007) and Caillé (2008), of the dimension of the 
donation, freedom and spontaneity. The gift has value and values those who give it, as long as freedom and originality exceed the part of the obligation, and "the dimension of disinterest, towa

rds others, is more important than the dimension of the personal interest, towards itself. It is this excess of freedom over the obligation that forms and measures the donor's value" (Caillé, 2008: 160).

Each culture contains the value of something that comprises human plurality, such as literature, works of art, symbols, and codes of behaviour, among others. It is in relation to this constitutive plurality that Arendt ([1958] 2007) invites us not only to adopt an attitude of astonishment and admiration, but also to recognize that on Earth, which is our common home, there is a person, a group of people or a people who have a position in the world that cannot be reproduced or replaced and a world view that only they can embody. For this reason, Arendt insists that the alliance is the heart of politics conceived as the space for relationships between peoples and between cultures. She reminds us that the peace and covenant treaties in Western societies are notions of Roman origin that made it possible to create a common world, transforming yesterday's enemies into tomorrow's friends.

In order to conclude this encounter of the struggle with the gift within a theory of recognition, we draw on the analysis of Paul Ricoeur ([2004] 2010 and 2006). For this author, the mutuality of the giving relationship, or the exchange of gifts as a process of symbolic recognition, are placed between the ceremonial and the moral sense. By denouncing the "unhappy conscience" or the "bad infinity" that an ever-demanding subject may have, the author "is telling us, in a way, that before demanding recognition, we should happily grant it. (...) Recognize, before demanding recognition for oneself", as Gonçalo Marcelo writes (2011: 123). By introducing dissymmetry at the centre of reciprocity, Ricoeur is both asserting the difference between people and putting the other before himself. And if recognition is granted to us, we must act with gratitude, recognize in return. Even if I am not obliged to repay, if I don't, I can break the social bond. Thus, "Ricoeur proposes an asymmetric, altruistic recognition relationship through which the other assumes a certain verticality: I must recognize the other in the first place" (Marcelo, 2011: 123). This verticality in the relationship with the other does not make him inaccessible, since the ceremonial character of recognition allows horizontality in human interactions.

Thus, by proposing an altruistic subjectivity, Ricoeur is building a pure ethics of recognition, based on states of peace, on gift practices that constitute a sphere of meaning and give us a normative supplement as the ideal regulator of our actions.

\section{Final considerations}

This text first addressed the justification of human rights, reflecting on themes that influence International Relations, such as the universality and the diversity of these same rights, with the contribution of several authors. Emphasis was placed on Benahbib, who defends this dialectic in terms of the right to have rights, previously stated by Harendt, in order to expand the achievements of this historic struggle.

Then Honneth's critical theory of recognition was developed by bringing in other theories by Ricoeur and Caillé, with the aim of contributing to the ethical renewal of human rights. 
A second discourse on recognition not limited to the perspective of the struggle or the consideration of an instrumental objective was then built, which completes itself in the otherness, through recognition and gift.

After presenting the struggle for recognition, which, in order not to fail, needs ethics with normative content, we completed the struggle with the gift, as both are poles of a recognition relationship.

Removing the Kantian categorical imperative that supposes a single rationality, the western one, human rights were taken to the ethical level, to dialogue, to the otherness, to the encounter with the other. Thus, recognition and gift are assumed as authentic assumptions of the political space.

\section{References}

Agamben, Giorgio. (2007). Homo sacer I: o poder soberano e a vida nua. Translated by Henrique Burigo. 2nd ed. Belo Horizonte: UFMG.

Arendt, Hannah. ([1949] 1973). Origens do totalitarismo. Translated by Roberto Raposo. São Paulo: Companhia das Letras.

Arendt, Hannah. ([1958] 2007). A condição humana. Translated by Roberto Raposo. Rio de Janeiro: Forense Universitária.

Assembleia Geral das Nações Unidas. ([1948] 1998). Declaração Universal dos Direitos Humanos. Brasília: UNESCO.

Benhabib, Seyla. (1992). Situating the Self. New York: Routledge.

Benhabib, Seyla. (2006). Another Cosmopolitanism. Sovereignty, Hospitality, and Democratic Iterations. New York and London: Oxford University Press.

Benhabib, Seyla. (2008), "Otro universalismo: Sobre la unidad y diversidadde los derechos humanos". Translated by David Álvarez. ISEGORÍA. Revista de Filosofía Moral y Política, No 39, July-December, 175-203.

Capella, Juan Ramón. (2005). Los ciudadanos siervos. Madrid: Editorial Trotta.

Capella, Juan Ramón. (2007). Entrada en la barbarie. Madrid: Editorial Trotta.

Caillé, Alain. (2008). "Reconhecimento e Sociologia". Translated by Maíra Albuquerque. Revista Brasileira de Ciências Sociais, vol. 23, n. 66, 151-163.

Caillé, Alain. (2010). "Vers une societé de convivialite avancee?" Recontre de Tokyo, 1010 Juillet.

Comparato, Fábio Konder. (2010). A afirmação histórica dos Direitos Humanos. São Paulo: Editora Saraiva.

Fistetti, Francesco. (2007). "Justice sociale, justice globale et obligation de donner". Revue du Mauss, no. 30, SECOND semester, pp. 279-300.

Fontes, Paulo. (2016). Autenticidade, reconhecimento e dádiva: para uma renovação dos Direitos Humanos. Doctoral Thesis in Legal-Political Theory and International Relations. Évora: Universidade de Évora. Available at: URL: https://dspace.uevora.pt/rdpc/bitstream/10174/18727/1/Tese.pdf 
Honneth, Axel. ([1992] 2011). Luta por reconhecimento: para uma gramática moral dos conflitos sociais. Translated by Jorge Telles de Menezes. Lisbon: Edições 70.

Honneth, Axel. (1999). Suffering from indeterminacy. An attempt at reactualization of Hegel's philosophy of right. Translated be Jack Ben-Levi. Amsterdam: Spinoza Lectures.

Honneth, Axel. ([2000] 2007). Disrespect: the normative foundations of critical theory. Translated b John Farrel and Joseph Ganahl. Malden: Polity Press.

Honneth, Axel. ([2001] 2010). The pathologies of individual freedom: Hegel's social theory. Translated by Ladislaus Löb. New Jersey: Princeton University.

Honneth, Axel. (2009). Patologias de la Razon. Translated by Griselda Mársico. Madrid: Katz.

Ignatieff, Michael. (2003). Los derechos humanos como política e idolatría. Barcelona: Paidós.

Marcelo, Gonçalo. (2011). Paul Ricoeur and the Utopia of Mutual Recognition. Études Ricoeuriennes / Ricoeur Studies, Vol 2, No 1 (2011), pp. 110-133. Available at: http://ricoeur.pitt.edu/ojs/index.php/ricoeur/article/view/69/20. Retrieved on 07/08/2014.

Mauss, Marcel. ([1924] 1988). Ensaio sobre a Dádiva. Translated by António Filipe Marques. Lisbon: Edições 70.

Kelsen, Hans. ([1960] 1998). O problema da justiça. Translated by João Baptista Machado. 3rd ed. São Paulo: Martins Fontes.

Peces-Barba, Gregorio. (1989). "Sobre el fundamento de los derechos humanos: um problema de moral y derecho", in Gregorio Peces-Barba Martínez (eds.), El fundamento de los derechos humanos. Madrid: Debate, pp. 265-277. Available at: http://hdl.handle.net/10016/12917. Retrieved on 09/050/2013.

Piovesan, Flávia. (2010). Direitos humanos e o direito constitucional internacional. 11. ed. São Paulo: Saraiva.

Rémy, Julien \& Caillé, Alain. (2007), "Ne vous demandez pas ce que vous pouvez faire pour I'Afrique". La Revue du MAUSS permanente, 18 August.

Ricoeur, Paul. ([2004] 2010). A luta pelo reconhecimento e a economia do dom. Translated by Cláudio Reichert do Nascimento and Noeli Dutra Rossatto. Ethic@ - Revista Internacional de Filosofia da Moral, v. 9, n. 2, 357-367.

Ricoeur, Paul. (2006). Percurso do reconhecimento. Translated by Nicolás Nyimi Campanário. São Paulo: Edições Loyola.

Rocha-Cunha, Silvério da. (2015). Crítica da razão simplificadora - escritos sobre poder e cidadania numa era de compreensão. V. N. Famalicão, Edições Húmus.

Santos, Boaventura Sousa. (2003). Por uma concepção multicultural de direitos humanos. in B. S. Santos (org.). Reconhecer para libertar. Os caminhos do cosmopolitismo multicultural. Rio de Janeiro: Civilização Brasileira, pp. 427-461.

Taylor, Charles. ([1992] 2009). A ética da Autenticidade. Translated by Luís Lóia. Lisbon: Edições 70. 